\title{
トウモロコシ花粉飛散および交雑抑制に対して効果的 な防風施設の配置方法に関する数值実験
}

\author{
牛山朋来 $^{\dagger}$ ・芝池博幸・杜 明遠 \\ ( 農業環境技術研究所)
}

\author{
Numerical study of the effective arrangements of windbreaks \\ to suppress maize pollen dispersal and cross-pollination \\ Tomoki UshiYama ${ }^{\dagger}$, Hiroyuki Shibaike, and Du Mingyuan \\ (National Institute for Agro-Environmental Sciences, Tsukuba, 305-8604 Japan)
}

\begin{abstract}
Windbreak nets and plant windbreaks are effective in suppressing maize pollen dispersal and crosspollination. This paper seeks effective arrangements of windbreak nets or plant windbreaks to suppress cross-pollination from a $50 \mathrm{~m}$ square maize donor plot. A pair of numerical models, the A2Cflow and A2Ct\&d, which had previously validated the pollen dispersal and cross-pollination in the maize plot, were used. 3-m tall 1-mm mesh nets and 2-m tall sorghum windbreaks were confirmed to be effective in suppressing cross-pollination in a $1.8-\mathrm{m}$ tall maize plot. The isolation distance for a $0.9 \%$ criterion of cross-pollination rate was reduced from $50 \mathrm{~m}$ without a windbreak to $22 \mathrm{~m}$ when four lines of windbreak nets were arranged. The wind speed was $3 \mathrm{~ms}^{-1}$. In commercial cultivation, plant windbreaks may reduce installation and labor costs rather than windbreak nets. Three lines of plant windbreaks are equivalent to a one line windbreak net in suppressing cross-pollination.
\end{abstract}

Key words: Maize pollen, Numerical simulation, Windbreak forest, Windbreak net.

キーワード : 数值シミュレーション, トウモロコシ花粉, 防風植生, 防風ネット

\section{1. はじめに}

防風ネットは，作物の風害防除や飛砂防止，土壌侵食 防止，気温や地温上昇などの目的でしばしば使用される 資材で (真木ら 1993, Maki et al., 2004), 防風林に 比べて短期間で安価に設置することができる。防風ネッ トや防風林の周囲の風速低減効果については, 数值シ ミュレーションによって詳しく調査されている(Wang and Takle, 1995 ; 1996 ; Wang et al., 2001 ; Bourdin and Wilson, 2008)。同様に, これらの作物増産効果や 土㙥侵食防止効果についても議論されている(Cleugh, 1998 ; Takahashi et al., 1998)。また, 風洞実験抽よび 数值実験によって, 実際に入手可能な防風ネットの防風 効果についても検証が行われている(牛山ら，2009)。

近年，遺伝子組換え作物に導入された遺伝子の拡散を

2010 年 11 月 4 日 受付, 2011 年 3 月 15 日 受理

${ }^{\dagger}$ Corresponding Author: ushiyama55@pwri.go.jp
防止するために，花粉飛散にともなう遺伝子フローの実 態調查が進められている(川島ら，2004)。これは，あ る作物について, 除草剂抵抗性などの特性を発現させる ために人為的に遺伝子が導入された遺伝子組換え品種 と, 慣行農法で用いられる従来品種が隣接して栽培され た場合に, 風に乗って花粉が群落間を移動し交雑するこ とによって, 導入された遺伝子が従来品種に拡散するとい う問題である。防風ネットは，このような導入遺伝子の拡 散を抑制するための手段としても有効であることが圃場実 験や数值実験によって確認されている (Ushiyama et al., 2009b)。しかしながら, これまでの研究では, 防風ネット の規格 (高さや目合い) による効果については議論されて いるものの, 防風ネットの配置については調査されていな い。

そこで本研究では, 花粉拡散に伴う導入遺伝子の拡 散を防ぐための効果的な防風ネットの配置について，す でに検証済みの防風ネットを用いて，数值実験による調 
査を行った。さらにUshiyama et al., (2009b)によって, 防風ネットと同様の交雑抑制効果を持つと報告されている ソルガムによる防風植生についても同様の調査を行った。

本研究で調査するトウモロコシは, 風媒性の雄性先熟 の作物であるため他の個体が放出した花粉を受粉しやす く, 花粉の寿命も 10 時間以上と長いために遠距離でも交 雑が起こりやすい。またトウモロコシは世界的にも栽培面 積が広く, 重要性が大きい作物である。本研究では $50 \mathrm{~m}$ 四方の圃場に花粉親群落を栽培した場合について調査を 行う。このように大きな戋場の場合, 複数の防風ネットや 防風植生を設置することにより, 単一の防風ネット等を設 置する場合よりも大きな交雑抑制効果を期待することがで きる。このような調査は実際の圃場実験により検証するこ とも可能であるが，一つの圃場について 1 年に 1 回しか データが取れないことや，気象条件や花粉放出を一定に 保つことが困難であること, 調査に多大な労力を必要とす ることなどから，まずは数值実験により設置を予定する防 風施設の配置方法について見当を付けることが先決であ る。本論文の 2 章では数值モデルと数值実験の方法, 3 章で結果，4 章で考察，5 章でまとめを行う。

\section{2. 実験方法}

\section{1 数値モデル}

使用した数值モデルは, Yamada Science \& Art 社に よって開発された A2Cflow (別名 HOTMAC, Yamada and Bunker, 1988) と呼ばれる大気モデルと, A2Ct \& d (別名 RAPTAD) と呼ばれる拡散輸送モデルである。前 者は, 3 次元大気場を予測する非静力学大気モデルであ り，乱流中の速度成分などの量を統計的な平均值とそれ からの偏差によって表現するレイノルズ平均モデルである。 乱流の表現は，2 次の乱流クロージャーを用いている。ま た, Yamada (1982)の植生キャノピーモデルが組み込ま れており，これを用いて風に対する植生や防風ネットの抵 抗を評価することができる。後者は, ラグランジュ法によ る拡散輸送モデルであり，A2Cflowによって求められた 気流をもとに, トレーサーの輸送を計算する。また，カー ネルと呼ばれる，ある空間分布をもったトレーサーを用い ることにより, 少ない計算量で滑らかな輸送分布を計算す ることができる。モデルの乱流過程は数 $\mathrm{m}$-数 $10 \mathrm{~km}$ ス ケールの現象の計算に適用することができる。Yamada and Bunker (1988) に詳しい説明がある。

\subsubsection{A2Cflow モデル}

以下，方程式系の基本部分を説明する。平均流の運動 方程式は,

$$
\frac{\partial u}{\partial t}-f V=-\frac{1}{\langle\rho\rangle} \frac{\partial p}{\partial x}+\frac{\partial}{\partial z}(-\overline{u w})-\eta C_{d} a(z) U|U|
$$

$$
\frac{\partial v}{\partial t}+f U=-\frac{1}{\langle\rho\rangle} \frac{\partial p}{\partial y}+\frac{\partial}{\partial z}(-\overline{v w})-\eta C_{d} a(z) V|V|
$$

ここで, $U, V$ は平均風速の $x, y$ 成分である。 $u, v, w$ は, 風速摂動成分の $x, y, z$ 成分; $f$ はコリオリパラメータ; $\langle\rho\rangle$ は水平平均空気密度 $; p$ は気圧摂動; $\eta$ は植生面積 比率で, $0 \leq \eta \leq 1 ; C_{d}$ は抵抗係数; $a(z)$ は植生密度 $\left(\mathrm{m}^{2}\right.$ $\mathrm{m}^{-3}$ )である。式 (1), (2) の最後の項が植生による抵抗を 表わす。オーバーラインは，アンサンブル平均を表わす。

乱流エネルギー方程式は以下のようになる,

$$
\begin{aligned}
\frac{\partial\left(\frac{q^{2}}{2}\right)}{\partial t}= & \frac{\partial}{\partial t}\left[q l \tilde{S}_{q} \frac{\partial\left(q^{2} / 2\right)}{\partial z}\right]-\overline{u w} \frac{\partial U}{\partial z}-\overline{v w} \frac{\partial V}{\partial z} \\
& +\beta g \overline{w \theta_{v}}-\frac{q^{2}}{B_{1} l}+\eta C_{d} a(z)\left[|U|^{3}+|V|^{3}\right]
\end{aligned}
$$

そして, 乱流長さスケール lは次の式によって得られる。

$$
\begin{aligned}
\frac{\partial\left(q^{2} l\right)}{\partial t}= & \frac{\partial}{\partial t}\left[q l \tilde{S}_{q} \frac{\partial\left(q^{2} l\right)}{\partial z}\right] \\
& -l E_{1}\left[-\overline{u w} \frac{\partial U}{\partial z}-\overline{v w} \frac{\partial V}{\partial z}+\beta g \overline{w \theta_{v}}\right] \\
& -\frac{q^{3}}{B_{1}}\left[1+E_{2}\left(\frac{l}{k z}\right)^{2}\right] \\
& +2 \eta C_{d} a(z) l\left[|U|^{3}+|V|^{3}\right]
\end{aligned}
$$

ここで, $q^{2}=\overline{u^{2}}+\overline{v^{2}}+\overline{w^{2}}$ は, 乱流運動エネルギー (TKE)の 2 倍; $\overline{w \theta_{v}}$ は乱流浮力フラックス ; $E_{1}, E_{2}$, $\tilde{S}_{q}, B_{1}$ は経験的定数 (それぞれ $1.8,1.33,0.2,16.6$ )

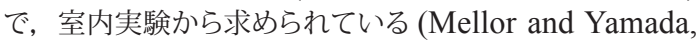
1982)； $\beta$ は熱膨張係数； $g$ は重力加速度； $\theta_{v}$ は仮温位 摂動である。式 (1) 〜 (4) の乱流フラックスは, 次の簡略 化した 2 次モーメント乱流クロージャ方程式, $(\overline{u w}, \overline{v w})$ $=-l q \tilde{S}_{M}\left[\frac{\partial U}{\partial z}, \frac{\partial V}{\partial z}\right], \overline{w \theta}=-\alpha l q \tilde{S}_{M} \frac{\partial \theta}{\partial z}, \quad$ ここで $\tilde{S}_{M}$ と $\alpha$ は, フラックスリチャードソン数の関数であり, $\alpha \equiv K_{H}$ $K_{M}^{-1}, K_{H}$ は渦拡散係数, $K_{M}$ は渦粘性係数である。

キャノピーモデルは，植生上で放射によって生ずる加熱 や冷却の, 大気との熱の出入りも予測している。内部熱 エネルギー方程式は以下で与えられる。 


$$
\begin{aligned}
\frac{\partial \theta}{\partial t}= & \frac{\partial}{\partial z}(-\overline{w \theta})+\frac{(1-\eta)}{\rho C_{p}} \frac{\partial R_{N}}{\partial z} \\
& +\frac{\eta}{\rho C_{p}}\left(1+\frac{1}{B}\right)^{-1} \frac{\partial R_{N P}}{\partial z}
\end{aligned}
$$

ここで, $B$ はボーエン比 $(H / L E)$ であり, 植生内では一 定と仮定する。水蒸気混合比の保存式は, 以下で与えら れる。

$$
\frac{\partial Q_{v}}{\partial t}=\frac{\partial}{\partial z}(-\overline{w q v})
$$

ここで, $Q_{v}$ と $q_{v}$ は平均と摂動成分の水蒸気混合比であ る。蒸発散に伴う水蒸気の出入りは, 本研究では無視する。

式(1)-(6)の下面境界条件は, Dyer and Hicks (1970) の経験式に基づいた, 無次元風と温度プロファイルによっ て決められる。地表面温度は, 放射, 顕熱, 潜熱を含む 熱伝導方程式を解くことによって求められる。地中 $50 \mathrm{~cm}$ の温度は， $25^{\circ} \mathrm{C}$ に固定している。 $U$ と $V$ に関する上面境 界条件は地衡風によって与え, 乱流は消滅すると仮定して いる。雲水や雨などの雲物理パラメータは, 本研究では 計算していない。非静力学気圧摂動は, Hirt and Cook (1972) に従って計算している。

\subsubsection{A2Ct \& d モデル}

$\mathrm{A} 2 \mathrm{Ct} \& \mathrm{~d}$ モデルは, ラグランジュ的手法に基づき, A2Cflow モデルによって得られた風速場を用いてトレー サー粒子の拡散輸送を求めるモデルである。

トレーサー粒子の位置は次の式によって求められる。

$$
x_{i}(t+\Delta t)=x_{i}(t)+U_{p i} \Delta t
$$

ここで,

$$
\begin{aligned}
& U_{p i}=U_{i}+u_{i} \\
& u_{i}(t+\Delta t)=a u_{i}(t)+b \sigma_{u_{i}}^{\zeta} \\
& +\delta_{i 3}(1-\alpha) t_{L x_{i}} \frac{\partial}{\partial x_{i}}\left(\sigma_{u_{i}}^{2}\right)
\end{aligned}
$$

$$
\begin{aligned}
& \alpha=\exp \left(-\frac{\Delta t}{t_{L x_{i}}}\right) \\
& b=\left(1-a^{2}\right)^{1 / 2}
\end{aligned}
$$

上の式で, $U_{p i}$ は $x_{i}$ 方向の粒子の速度, $\zeta$ はガウス分 布のランダム数で, 平均が 0 , 大きさが 1 の分散を持つ。 $t_{L x_{i}}$ は, 速度 $u_{i}$ のラグランジュ積分時間, $\sigma_{u_{i}}$ は速度摂動 $u_{i}$ の標準偏差, $\delta_{i 3}$ はディラックのデルタである。平均風 速 $U_{i}$ と風の標準偏差 $\sigma_{u_{i}}$ は A2Cflow モデルから得られ る。式 (9) の最後の項は, 乱流エネルギーが小さい領域 に粒子が溜まるのを補正するためのものである。本研究 では, ラグランジュ時間スケール $t_{L z}=20 s, t_{L x}=t_{L y}=$ $10^{4} \mathrm{~s}$ を用いた。

理論的には, ある時刻と場所における粒子の集積密度 を求めるには, 無限個の粒子の航跡を計算する必要があ る。ここでは, 有限個の粒子の計算により滑らかな分布を 予測するため, カーネル密度記述子を導入した (Yamada and Bunker, 1988)。これは, カーネルの中心の周囲に ガウス分布に従う密度分布を持つものであり, 密度分布の 分散は速度分散の積分值によって決められる。そして，あ る時刻と位置におけるトレーサー密度は, 該当するカーネ ルが持つ密度分布の和として表現される。

$(X, Y, Z)$ におけるトレーサーの集積密度 $\chi$ は次の式に よって表わされる。

$$
\begin{aligned}
\chi(X, Y, Z)= & \frac{Q \Delta t}{(2 \pi)^{3 / 2}} \sum_{k=1}^{N} \frac{1}{\sigma_{x k} \sigma_{y k} \sigma_{z k}} \\
& \exp \left(-\frac{1}{2} \frac{\left(x_{k}-X\right)^{2}}{\sigma_{x k}^{2}}\right) \\
& \times \exp \left(-\frac{1}{2} \frac{\left(y_{k}-Y\right)^{2}}{\sigma_{y k}^{2}}\right) \\
& \times\left\{\exp \left(-\frac{1}{2} \frac{\left(z_{k}-Z\right)^{2}}{\sigma_{z k}^{2}}\right)\right. \\
& \left.\exp \left(-\frac{1}{2} \frac{\left(z_{k}+Z-2 z_{g}\right)^{2}}{\sigma_{z k}{ }^{2}}\right)\right\}
\end{aligned}
$$

ここで, $\left(x_{k}, y_{k}, z_{k}\right)$ は $k$ 番目の粒子の位置; $\sigma_{x k}, \sigma_{y k}$, $\sigma_{z k}$ はガウス分布の標準偏差 $; z_{g}$ は地表高度である。分 散 $\sigma_{y}$ は次のように近似される :

$$
\begin{aligned}
& \sigma_{y}=\sigma_{v} t \text { for } t \leq 2 t_{L y} \\
& \sigma_{y}{ }^{2}=2 t_{L y} \sigma_{v}{ }^{2} t \text { for } t>2 t_{L y}
\end{aligned}
$$

\section{2 モデル設定}

実験対象としたトウモロコシ圃場の配置を Fig. 1 に示 す。花粉親群落は $51 \mathrm{~m} \times 51 \mathrm{~m}$, 種子親群落は $51 \mathrm{~m}$ $\times 100.5 \mathrm{~m}$ であり,それらの周囲に幅 $19.5 \mathrm{~m}$ の緩衝区 (ソルガムを栽培) を設けた。花粉親と種子親群落の境界 には幅 $3 \mathrm{~m}$ の裸地を設けた。花粉親と種子親のトウモロ コシおよび緩衝区のソルガムの高さはすべて $180 \mathrm{~cm}$ とし た。この実験圃場を数值モデルで表現する際に，水平格 子間隔は $1.5 \mathrm{~m}$, 鉛直格子間隔は下層 $3.6 \mathrm{~m}$ までは 0.3 $\mathrm{m}$ 間隔，それより上層では徐々に大きくして上部境界付近 


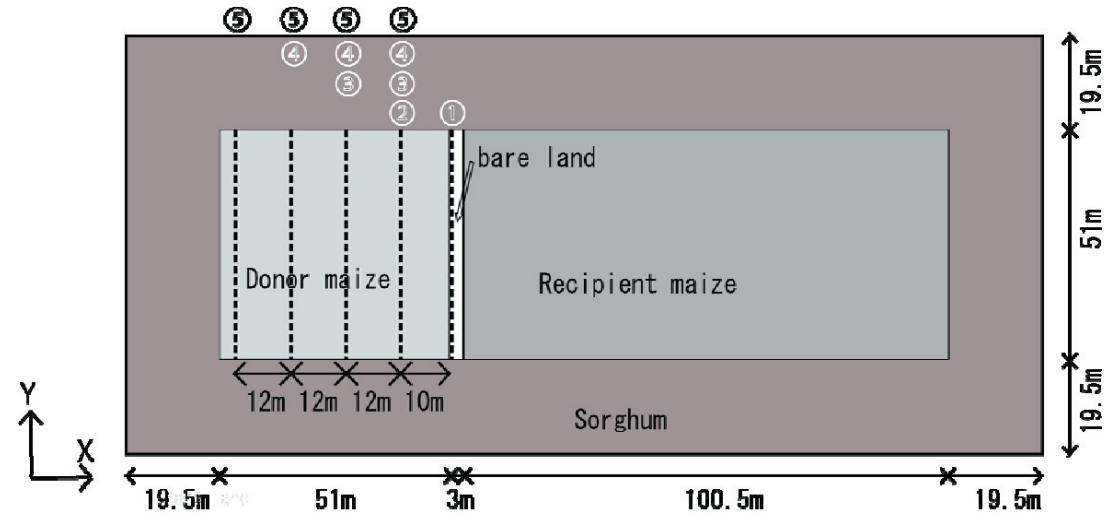

Fig. 1. Arrangement of the numerical domain. Broken lines in the donor plot are locations of windbreaks. See text.

では $20 \mathrm{~m}$ とした。実験領域は $189 \mathrm{~m} \times 88.5 \mathrm{~m} \times 300$ $\mathrm{m}$ である。

$\mathrm{A} 2 \mathrm{Ct}$ \& d モデルの計算で必要となる，トウモロコシ花 粉の落下速度は Aylor (2002) を参考に $0.3 \mathrm{~ms}^{-1}$ とした。 また，花粉放出率は雄穂付近の気温の関数として与えた (川島ら，2004)。このため，午前 9 時頃に花粉放出率は 最大となった。なお，地面や葉などに落下して沈着した花 粉の跳ね返りや再飛散は，計算が複雑になるため考慮し なかった。これらを考慮しなくてもある程度の精度で交雑 分布が得られることは報告されている(Ushiyama et al., 2009b)。

数值計算は，一つの設定につき午前 6 時から午後 6 時 までの 12 時間行った。太陽放射はトウモロコシ開花期に 対応する 2007 年 8 月 21 日の太陽高度をもとに計算した。 また, 気温・水蒸気量の初期值扔よび境界条件は気象庁 作成の GPV の 2007 年 8 月 21 日のデータを用いた。た だし，風のみは全層で $x$ が正の向き (Fig. 1 で右向き) に $3 \mathrm{~ms}^{-1}$ を初期值および境界条件として与えた。風速 3 $\mathrm{ms}^{-1}$ の值は, Ushiyama et al., (2009a, 2009b)で行わ れた茨城県つくば市や群馬県嬬恋村での実験戋場におい て,トウモロコシの開花期である 8 月の好天日の風速約 1.5 $\mathrm{ms}^{-1}$ の 2 倍とした。これらの期間でも, 台風などに伴い 3 $\mathrm{ms}^{-1}$ 以上の風が吹く可能性は否定できないが，その場合 は降水を伴うことが多いため花粉飛散に対する影響は小さ いと考えられる。

\section{3 ネットおよび防風植生の配置}

Fig. 1 の花粉親群落内に破線で描かれているのが，防 風ネットまたは防風植生の位置である。防風ネットは，高 さ $3 \mathrm{~m}$, 格子間隔 $1 \mathrm{~mm}$ のポリエチレンネットを想定して いる。その風の抵抗係数は風洞実験から得られており (牛 山ら, 2009), $C_{d}=1.02, a(z)=10.0$ である。防風植
生は, 高さ $2 \mathrm{~m}, C_{d}=0.2, a(z)=10.0$ とした (Ushiyama et al., 2009b)。一方，作物であるトウモロコシは， $C_{d}=$ $0.2, a(z)=1.05$ とした。防風ネットは幅 1 列の格子で表 現し, 防風植生の場合は幅 2 列の格子で表現した。これは, 実際に防風植生の場合には $3 \mathrm{~m}$ 程度の幅を持って生育さ せることが想定されるためである。

数值実験により検証した防風施設の配置は, Fig. 1 に ある(1)〜(5)の 5 種類および防風施設の無い場合である。

$1 \mathrm{~mm}$ 目の防風ネットを 1 列配置した場合, 約 $60 \%$ 以 下に風速を抑制する効果があるのは風下側に約 $9 H$, 風 上側に $1 H$ である。ただし， $H$ はネットの高さである。し たがって, 今回の実験設定では，防風ネットの有効高さ が, $3 \mathrm{~m}-1.8 \mathrm{~m}=1.2 \mathrm{~m}$ と考えると, 上記の風速抑制効 果が見込まれるのは風下側 $10.8 \mathrm{~m}$, 風上側 $1.2 \mathrm{~m}$ である。 したがって，理論的には $12 \mathrm{~m}$ 毎に防風ネットを設置する ことによって，花粉親群落のすべての領域で風速を $60 \%$ 以下に抑えることができるはずである。その原理をもとに して，防風ネットの数を省いた場合の交雑抑制効果も調 べるため，以下のような防風施設の配置について数值実 験を行った。な押，抑風効果を $60 \%$ とする值は，防風施 設を設置するための費用対効果を考慮して設定した。

配置(1)，単純に花粉親と種子親群落の境界に防風施 設を配置したものである。配置(2)は，防風施設の風下側 の風速抑制領域を有効に利用して, 花粉親群落の花粉の 巻きあがりを抑えることを目的に，花粉親と種子親の境界 より $10 \mathrm{~m}$ 上流側に防風施設を設置したものである。配置 (3)は配置(2)に加えて，さらにその $12 \mathrm{~m}$ 上流側に防風施 設を設置したもの，配置(4)，(5)それれぞれさらに上流側 $12 \mathrm{~m}$ 毎に 1 本ずつ防風施設を増やした場合である。

なお，防風植生についても同じ位置に設置することを 前提にして, 数值実験を行った。防風植生は高さが $2 \mathrm{~m}$ 
なので, 周囲のトウモロコシに比べて $0.2 \mathrm{~m}$ 高いだけで ある。しかし, 周囲のトウモロコシに比べて 10 倍密に植 えられることを仮定しているので, 群落内部拉よび雄穂の 高さ $(180 \mathrm{~cm})$ 周辺における風速はある程度抑えることが 期待される。

交雑率 $C$ は, ある格子点における花粉親花粉濃度 $N_{D}$ と種子親花粉濃度 $N_{R}$ を用いて式 (14) のように計算した。

$$
C=\frac{\sum\left(N_{D}\right)}{\sum\left(N_{D}+N_{R}\right)}
$$

本来トウモロコシは雄性先熟の作物であるため, 数日間 の計算をする場合は開花期間中の雄穂と雌穂の開花のず れを考慮する必要があるが, 本研究では 1 日のみの計算 であるため, この効果は無視した。また交雑率は, 本来 雌しべに沈着した花粉数で表わすべきであるが，単位時 間当たりの沈着花粉数は花粉数濃度と同じ比率になるた めに, 本研究では花粉数濃度で代用した。この手法で精 度よく交雑率分布が計算できることは, Ushiyama et al. (2009b) に示されている。

\section{3. 結 果}

\section{1 交雑抑制効果}

Fig. 2 に防風ネットを設置しない場合と 5 種類の配置 に防風ネットを設置した場合の交雑率分布の数值計算結 果を示す。いずれの場合も交雑率は花粉親から離れるに 従って低下する。また防風ネットを設置しない実験から実 験(1)〜(5)まで全体的に交雑率が低下していることがわか る。

花粉親と種子親の境界にネットを設置した実験1 ( 長破 線)と,それよりも $10 \mathrm{~m}$ 上流にネットを設置した実験(2)(短 破線)を比較すると, (2)の方が全ての距離において明ら かに交雑率が低下している。これは，防風ネットによって，
花粉親群落の風下側端の風速を抑えた方が, 種子親群落 の風上側端の風速を抑えるよりも交雑抑制に対して効果的 であることを示している。したがって，交雑抑制には，花 粉親群落上層の風速を抑えることによって花粉親が放出す る花粉の舞い上がりを抑制することが有効であると推測さ れる。

続いて, 実験(3)，(4)，(5)はさらに上流側にも防風ネッ 卜を増やして花粉親群落上の風速を抑制した実験である。 それらの交雑率は，実験(3)実験(2に比べて顕著な抑制 効果の向上がみられるが, 以後 (4), (5)と上流側に増える に従い抑制効果は微増するにとどまっている。一方, 花 粉親からの距離が 70〜100 m の区間では, 実験(5)結 果が(4)に比べて大幅に減少しているように見える。しかし， この付近では計算上の䛊差が大きくなるため, この差につ いては注目しない。

さらに，ヨーロッパで採用されている遺伝子組換え作物 の「意図せざる混入率 (adventitious contamination)」 の許容水準である $0.9 \%$ (Fig. 1 の水平線) を達成するた めに必要な花粉親と種子親群落の隔離距離 (Messean et al., 2006)を Table 1 にまとめた。防風ネットなしの場合 は $50 \mathrm{~m}$, 実験(1)では $40 \mathrm{~m}$, 実験(2)では $30 \mathrm{~m}$, 以下ネッ トの本数が増えるに従って, $27 \mathrm{~m}, 25 \mathrm{~m}, 22 \mathrm{~m}$ と減少 した。結果を隔離距離の観点から整理すると, ネット無し の場合に比べて 1 本の防風ネットを設置することによって 隔離距離を 60 \%に短縮することができ, 防風ネットを 3 本以上用いることにより, 隔離距離を $50 \%$ 以下に短縮で きることが示された。

次に，防風植生を用いた実験による交雑率分布を Fig. 3 に示す。こちらも防風ネットの場合と同様に, 防風植 生の列が増えるに従って, 交雑抑制効果が増加している。 しかし, 防風植生が最も多い実験(5)場合でも, 花粉親 から最も遠い地点での交雑率は $0.09 \%$ であり, 防風ネッ

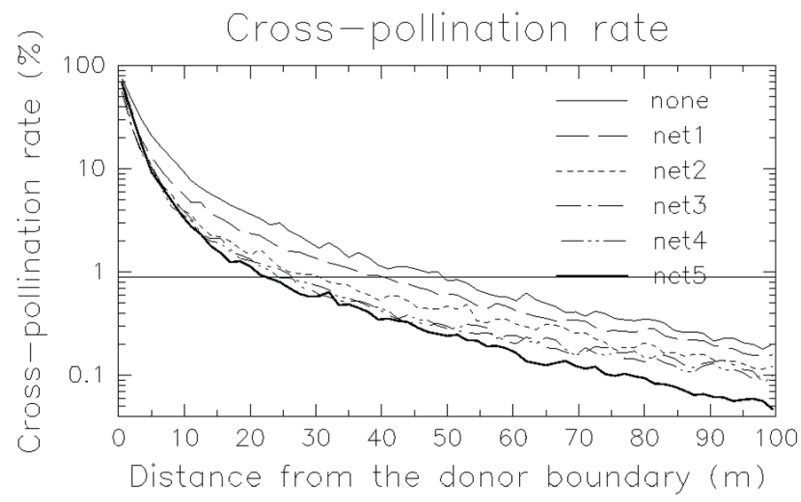

Fig. 2. Cross-pollination rate for windbreak net experiments averaged with the distance from the donor boundary. A horizontal line indicates $0.9 \%$ cross-pollination rate. 
Table 1. Isolation distance for net and plant windbreak cases with respective windbreak arrangements.

\begin{tabular}{lcccccc}
\hline Arrangement number & none & 1 & 2 & 3 & 4 & 5 \\
\hline Windbreak net & 50 & 40 & 30 & 27 & 25 & 22 \\
\hline Plant windbreak & 50 & 40 & 35 & 33 & 32 & 31 \\
\hline
\end{tabular}

トの場合の $0.05 \%$ に比べて大きな交雑率が示された。

防風植生を設置した場合についても，交雑率を $0.9 \%$ 以下に抑えるために必要な隔離距離を Table 1 に示した。 防風植生なしの場合の $50 \mathrm{~m}$ に対して, 実験(1)で約 $40 \mathrm{~m}$, 実験(2)で $35 \mathrm{~m}$, 実験(3)〜(5) 31-33 m 程度である。こ の結果から，防風施設が11の位置にある場合には，隔離 距離が防風ネットと防風植生とで変わらないことがわかる。 しかし，実験(2)位置では防風ネットの場合の $30 \mathrm{~m}$ に 比べて防風植生ではやや長い $35 \mathrm{~m}$ の隔離距離が必要で あり, 実験(3)〜 (5)については約 $33 \mathrm{~m}$ より隔離距離を短 縮することはできなかった。結果を隔離距離の観点から整 理すると, 防風植生を 1 列設置することにより隔離距離を $70 \%$ に短縮することができ，十分な交雑抑制効果が示さ れた。

以上の実験では風速や風向が一定の理想化された状態 を想定しているため，得られた結果をすぐに実用化に結 びつけることはできないが，実際に防風施設を設置する 場合の交雑率について非常に有用な目安が示されたと考 えられる。

\section{2 風速分布}

次に， 3.1 で述べた交雑抑制効果を生みだした要因を 解明するために，防風ネットおよび防風植生の風速抑制 効果を調べた。Fig. 4 は防風ネット, Fig. 5 は防風植生 の結果である。これらの図は, 計算時間の中間である正 午における，防風ネットや防風植生に垂直な鉛直断面に おける風速分布である。風速の值は，上流側末端を 1 と
した場合の比率で表わしている。まず Fig. 4 のネット 1 と 2 を比べると，抑制された風速の分布はほとんど同じで, 位置が変わっているだけである。ネット 1 の場合は，抑 風効果が大きいのは $70 \sim 80 \mathrm{~m}$ の領域であり, この領域 は種子親群落上流側末端に入り込んでいる。一方，ネッ ト 2 の場合は $60 \sim 70 \mathrm{~m}$ の領域で抑風効果が大きく, こ の領域は花粉親群落下流側末端に収まっている。つまり 花粉親群落内に占好抑風領域の大きさの違いが，実験 (1)と(2)で示された交雑率の差をもたらしたものと考えられ る (Fig. 2)。ネット $3 \sim 5$ については複数の防風ネットに より連続的に風速が抑制されており，ネット 5 については $20 \sim 70 \mathrm{~m}$ の花粉親全域にわたって風速が抑えられてい る。また，ネット 3 や 4 ではネット 5 と比べて花粉親群落 の上流側末端付近で風速が大きめである。しかし，花粉 親群落の上流側末端で巻きあげられた花粉も, 種子親群 落に達する前に防風ネットで弱められた風により花粉親群 落内に落下するものが多くなり, 結果としてネット 2 に比 べて交雑率が抑制されたものと考えられる。

一方防風植生の場合は (Fig. 5), 防風ネットに比べて 高さが低いために抑風効果は相対的に小さいものの，防 風ネットと同様に花粉親群落上層の風速が効果的に抑制 されている。

次に，防風ネットおよび防風植生を設置した場合の 雄穂高に抢ける絶対風速を Fig. 6 に示す。Fig. 6a の 防風ネットを設置した場合, Net 5 では花粉親群落内の $-50 \sim 0 \mathrm{~m}$ の領域で風速が $0.4 \sim 0.7 \mathrm{~ms}^{-1}$ に抑えられて いる。また, ネット 1 本よりも 2 本, 3 本と増えるに従って, 下流側の抑風効果もやや大きくなる傾向が見られた。

一方，Fig. 6b の防風植生による実験結果では，Fig. 6a の防風ネットと同様のパターンではあるが，抑風効果 が小さくなっている。これは，防風植生の高さが防風ネッ 卜に比べて低いことが主な原因と考えられる。最も抑風効

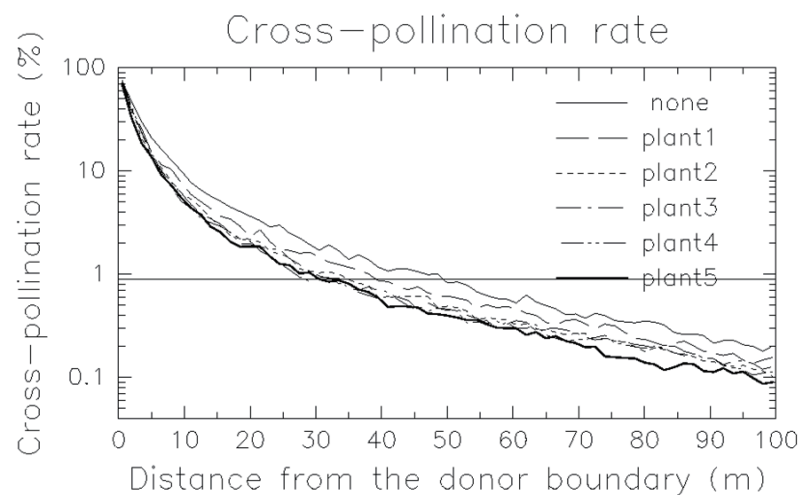

Fig. 3. Cross-pollination rate for plant windbreak experiments averaged with the distance from the donor boundary. A horizontal line indicates $0.9 \%$ cross-pollination rate 

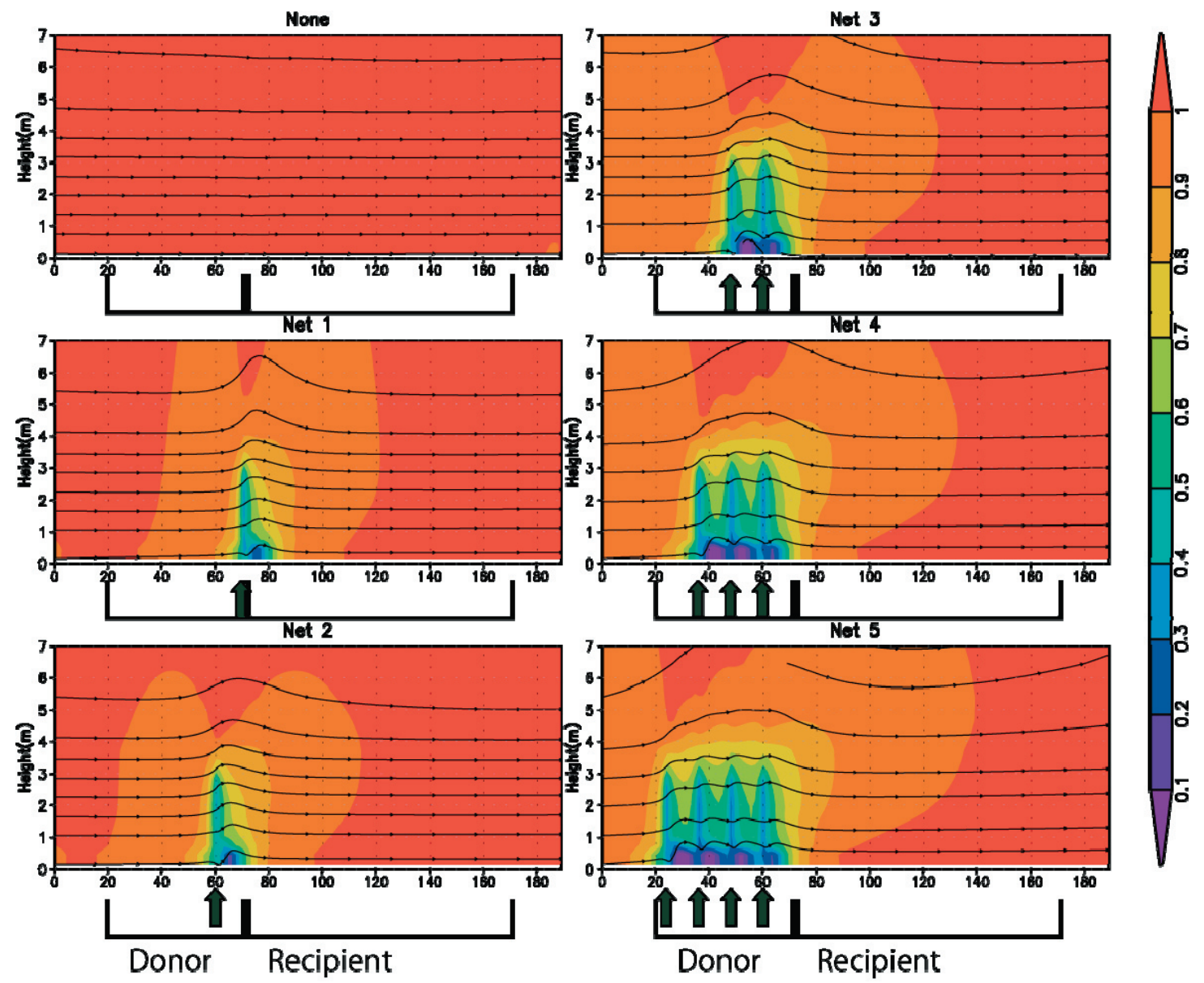

Fig. 4. Wind speed suppression rate with respect to the upstream boundary edge in windbreak net experiments described by color shade. The locations of the windbreak net are shown by arrows below the panel, and the donor and recipient plots are shown by brackets. 

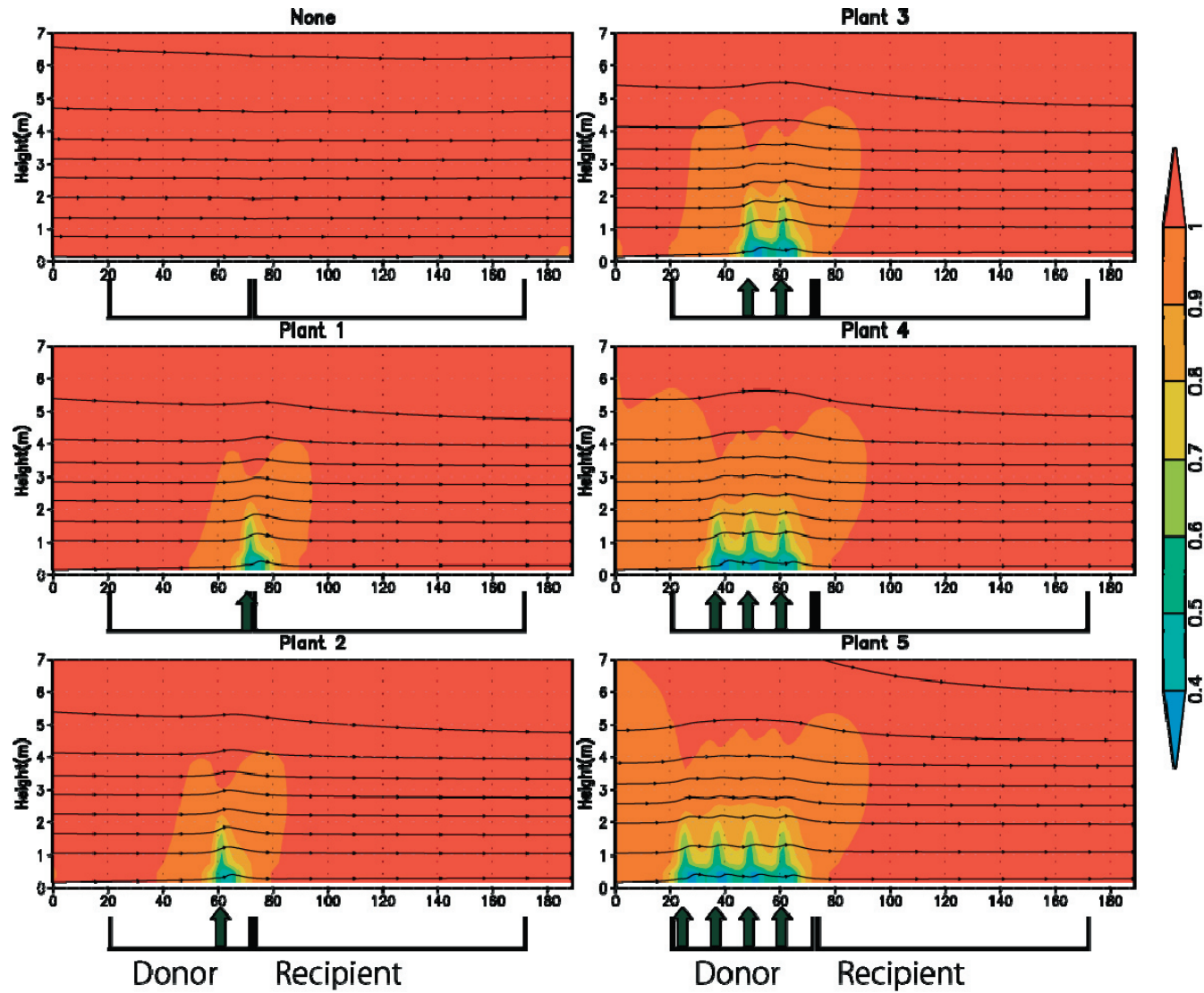

Fig. 5. Wind speed suppression rate with respect to the upstream boundary edge in plant windbreak experiments described by color shade. The locations of the windbreak net are shown by arrows below the panel, and the donor and recipient plots are shown by brackets.
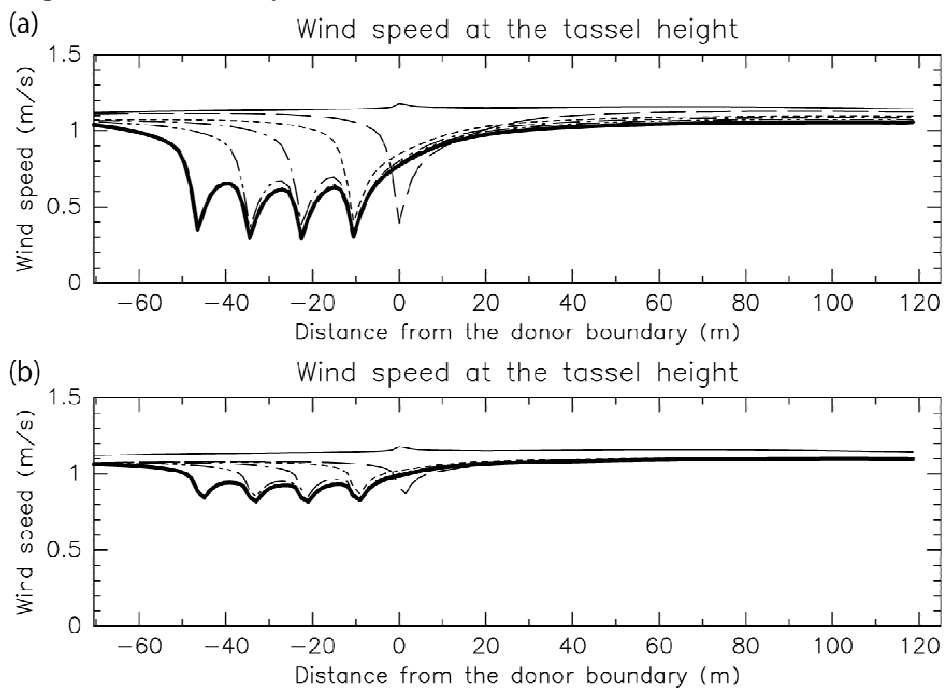

Fig. 6. Wind speed at the height of maize tassel for windbreak net experiment (a) and plant windbreak experiment (b). Line types are correspond to the windbreak arrangements, same as Fig. 2 and 3 as, thin solid line (1), long broken line (2), short broken line (3), dot broken line (4), double dot broken line (5), and thick solid line (6). 
果が高い Plant 5 では, 風速は $0.85 \sim 1.0 \mathrm{~ms}^{-1}$ に抑え られているが, これは上流側風速より $0.1 \sim 0.25 \mathrm{~ms}^{-1}$ 程 度小さくなっているに過ぎない。しかし，このようなわず かな抑風効果であっても交雑抑制に対して効果的であるこ とは, Fig. 3 で示された通りである。

\section{4. 考察}

今回の数值実験の結果から, 高さ $3 \mathrm{~m}$ の防風ネットお よび高さ $2 \mathrm{~m}$ の防風植生が, 作物高 $1.8 \mathrm{~m}$ のトウモロコ シに対して十分な交雑抑制効果があることが示された。こ れらは, 交雑率を $0.9 \%$ 以下に抑えるために必要な隔離 距離を, 防風施設が無い場合の $50 \mathrm{~m}$ から防風ネットを 設置することで最高 $22 \mathrm{~m}$, 防風植生を設置することで最 高 $31 \mathrm{~m}$ まで低減させることができた。しかし，これらは 風向風速を固定した理想化された条件での実験結果であ る。ここでは, 実際の戋場でトウモロコシを栽培する場合 に考慮すべき点について考察を行う。

まず, 風向風速が変わった場合の効果について考察 する。風向は, 今回の実験では最も交雑が起こりやす い, 花粉親群落から種子親群落の方向で行った。風向が 変わった場合には, 交雑率は一般的に減少する。なぜな ら, 花粉親群落から放出された花粉の多くは種子親群落 以外の領域に運ばれることになるからである。また, 防風 施設の位置が(2)～(5)の場合, 風向が斜めの場合 (例えば, Fig. 1 の右斜め下向き), 部分的に花粉親群落と種子親 群落の境界付近で防風施設の効果が無くなる領域が現れ る。したがって, そのような境界付近の種子親群落の風 上側 (この例の場合, Fig. 1 の種子親群落の左上部分) では局所的に交雑率が大きくなることが考えられる。しか しこの場合, 防風施設を外れて花粉親群落上空から種子 親群落上空に流れる気流は花粉親群落上空における吹走 距離が短いことと, 種子親群落上空に輸送される花粉親 花粉数は全体としては減少することから, 平均的な交雑率 は風向が花粉親群落から種子親群落方向に吹く場合に比 べて大幅に減少する (図は省略)。

風速については, 今回の実験では初期值として $3 \mathrm{~ms}^{-1}$ を仮定し，その後 1 日を通して上空の風速は $3 \mathrm{~ms}^{-1}$ を維 持するように設定した。一般的に関東では, トウモロコシ が開花する夏の晴天日の平均風速は $1.5 \mathrm{~ms}^{-1}$ 程度であり, 今回の設定は風速を 2 倍程度過大評価したものである。

したがって, 一般的な晴天日の条件のもとでは今回の実 験で求めた隔離距離により, 十分な交雑抑制効果が期待 できる。ただし, 台風などの場合 $3 \mathrm{~ms}^{-1}$ 以上の強風が吹 く恐れもあるが，このような場合は悪天であることが予想 されるので, 花粉はほとんど放出されず, 交雑には影響し ないものと予想される。
次に圃場面積について, 今回は花粉親群落を $50 \mathrm{~m}$ 四 方と仮定した。実際には，それよりも大きな戋場で商用栽 培が扔こなれることも想定される。しかし, 花粉親群落 と種子親群落の境界付近に設置された防風施設は交雑抑 制に効果的であったが，上流側に防風施設の本数を増や した場合の交雑抑制効果は限定的であった。このことから, 花粉親群落と種子親群落の境界から遠い上流側で放出さ れた花粉の多くは種子親群落に達する前に落下してしまう ため, 境界付近から放出された花粉に比べて交雑に対す る影響は小さいと推測される。そのため, 上流側に設置 した防風施設による交雑抑制効果は境界付近のものに比 べて小さいと考えられる。このことから, 花粉親群落が 50 $\mathrm{m}$ よりも大きくなった場合でも, 今回設定した防風施設は 十分な交雑抑制効果を発揮すると予想される。

数值実験では, より大規模な围場についても調査する ことは可能であるが, 本研究で使用したパーソナルコン ピュータでは, 計算能力の問題から今回の設定が限界で あった。ただし, 将来計算能力の高い計算機を利用して, さらに広い戋場について調査する可能性は残されている。

続いて, 防風施設の設置費用の点について考察す る。今回使用した防風ネットの規格は $1 \mathrm{~mm}$ 目のポリエ チレン製のもので, $2 \mathrm{~mm}$ 目以上のネットに比べ防風効 果が高いために実験資材として採用した。ちなみに, 1 $\mathrm{mm}$ 目ネットを $2 \mathrm{~mm}$ 目ネットに置き換えても, 交雑率は 20\%程度しか増加しない (Ushiyama et al., 2009b)。し かしながら，ネットを設置する場合には支持ポールを一 定間隔で建設する必要があり, 設置費用と作業時間が必 要となる。このため, 実際にはできるだけ防風ネットの設 置本数は減らすことが望ましい。防風ネットを 1 本のみ設 置する場合には, 数值実験で示したように, 単純に花粉 親群落と種子親群落の境界の Fig. 1 の11に設置するより は, より効果の大きい(2)の位置に設置するべきである。さ らに, ネットの本数を増やして交雑抑制効果を高める場合 は，(3)，(4)のように，上流側に増やしていくべきである。

防風ネットに代わって防風植生を用いる場合は, 設置 費用が軽減できると考えられる。栽培面積は多少犠牲に なるが, 栽培対象であるトウモロコシよりも生育が早く, よ り植生高の高いソルガムを密に栽培することによって, 効 果的な防風植生を完成させることができる。さらにトウモ ロコシの収穫後，ソルガムを土壌中に梳き込めば，翌年 の堆肥としても利用できる。また, 設置費用と作業時間が 防風ネットに比べて軽減できるため, 防風植生の本数を 増やすことも容易である。(2)の防風ネット 1 本と(4)の防風 植生 3 本による交雑抑制効果がほぼ同程度であることか ら，後者を選択することで経費を削減することができると 考えられる。 
今回の実験結果はすべて数值実験のみの結果であり, 実際の圑場における測定結果による検証は行うことがで きない。そこで, 数值実験結果の信頼性について, これ までの研究をもとに考察する。牛山ら (2009)では, 防風 ネットの風下側の防風効果について風洞実験を行い, そ の風速分布を $\mathrm{A} 2 \mathrm{C}$ モデルで再現した。数值実験の結果 は風洞実験を良く再現しており，精度についての正確な 記述はないものの, 図の比較から概ね $10 \%$ 以内と考えら れる。Ushiyama et al. (2009b) では, A2C モデルを用 いて防風ネットや防風植生によるトウモロコシの花粉交雑 抑制実験の圃場実験結果を再現した。その結果, 防風植 生による交雑抑制効果は, 花粉親から $52 \mathrm{~m}$ までのすべ ての実験領域で統計的に有意な精度で交雑率を再現した。 しかし, 高さ $6 \mathrm{~m}$ の防風ネットによる実験では, ネットか ら $25 \mathrm{~m}$ 以上離れた領域での精度が不十分であった。し かし, この不十分な精度はモデルに与えた境界条件のデー タの問題によるものと考えられるため, 必ずしも数值実験 の結果の信頼性を否定するものではない。これらのことか ら, 今回の数值実験による交雑分布は, 信頼性について 一定の検証を受けているものの, 精度についてはある程 度余裕を持って用いることが望ましい。

\section{5. まとめ}

防風ネットおよび防風植生によるトウモロコシの交雑抑 制手法として, 防風施設の効果的な配置について, 数值 実験により調べた。実験設定は，花粉親群落が $50 \mathrm{~m} \times$ $50 \mathrm{~m}$, それに隣接する種子親群落が $50 \mathrm{~m} \times 100 \mathrm{~m}$ で, 風向は花粉親群落から種子親群落方向, 風速は $3 \mathrm{~ms}^{-1}$ で一定とした。実験の結果, 限られた防風施設により効果 的に交雑を抑制するには, 花粉親群落の下流側端の風速 を抑えることが重要であることがわかった。そのためには, 防風施設を, 花粉親と種子親群落の境界よりもやや上流 側に設置することが有効であった。さらに, 花粉親群落内 の上流側にも防風施設を増やすことで, 花粉親群落内の 風速をより小さく抑えることができ, 交雑抑制に対して効 果的であった。

これらの効果について, 交雑率を $0.9 \%$ 以下に抑えるた めの隔離距離で評価すると, 風速 $3 \mathrm{~ms}^{-1}$ の場合におい て, 防風施設が無い場合の隔離距離 $50 \mathrm{~m}$ から, 防風ネッ トを設置することで $22 \mathrm{~m}$ まで最大短縮することができた。 また, 防風植生を設置することで最大 $31 \mathrm{~m}$ まで短縮でき ることが示された。実際の商業栽培においては, 広い圃 場に防風ネットを設置するためには経費と労働力を投資す ることが必要であり, ソルガム等の防風植生を栽培する方 が費用対効果に優れている場合も考えられる。そのような 場合, 防風植生を 3 本設置することにより, 防風ネット 1
本を設置するのとほぼ同じ交雑抑制効果を持つことが示さ れた。

\section{謝 辞}

数值モデルの使用にあたって, YSA Inc.の山田哲司 博士から数多くのアドバイスをいただいた。モデルの初期 值および境界条件として, 気象庁によって作成され, 京 都大学生存圈研究所によって NetCDF 形式に変換された GPVデータを使用した。図の作成には, 地球流体電脳 クラブライブラリ (DCL) と Grid Analysis and Display System (GrADS) を使用した。ここ感謝いたします。

\section{References}

Aylor, D. E., 2002: Settling speed of corn (Zea mays) pollen. J. Aerosol Sci., 33, 1601-1607.

Bourdin, P., and Wilson, J. D., 2008: Windbreadk aerodynamics: Is computational fluid dynamics reliable?. Boundary-Layer Meteorol., 126, 181208.

Cleugh, H. A., 1998: Effects of windbreaks on airflow, microclimates and crop yields. Agroforestry Systems, 41, 55-84.

Dyer, A. J., and Hicks, B. B., 1970: Flux-gradient relationship in the constant flux layer. Quart. $J$. Roy. Meteorol. Soc., 96, 715-721.

Hirt, C. W., and Cook, J. L., 1972: Calculating threedimensional flows around structures and over rough terrain. J. Comput. Phys., 10, 324-340.

川島茂人・松尾和人・芝池博幸・井上 聡・岡 三徳・杜 明遠・高橋裕一・米村正一郎, 2004: 気象条件が花粉 飛散を介してトウモロコシの交雑率に与える影響. 農業気 象, 60, 151-159.

真木太一・潘 伯荣・杜 明遠・上村賢治, 1993: 中国卜ル ファンの乾燥地に扔ける防風ネットによる微気象改良と飛 砂防止. 農業気象, 49, 159-167.

Maki, T., Hirayama, Y., Takemasa, A., and Obu, M., 2004: Meteorological alleviation by a windbreak net at reclaimed land of Isahaya Bay. J. Agric. Meteorol., 60, 243-251.

Mellor, G. L., and Yamada, T., 1982: Development of a turbulence closure model for geophysical fluid problems. Rev. Geophys. Space Phys., 20, 851-875.

Messean, A., Angevin, F., Gomez-Barbero, M., Menrad, K., and Rodriguez-Cerezo, E., 2006: New case studies on the coexistence of GM and 
non-GM crops in European agriculture. European Commission, European Science and Technology Observatory. EUR22102EN.

Takahashi, S., Du, M., Wu P, Maki, T., and Kawashima, S., 1998: Three dimensional numerical simulation of the flow over complex terrain with windbreak hedge. Environ. Model. Software, 13, 257-265.

Ushiyama, T., Du, M., Inoue, S., Shibaike, H., Yonemura, S., and Kawashima, S., 2009a: Threedimensional simulation of rice pollen dispersal and hybridization in field scale. Proceedings of the 5th WSEAS international conference on mathematical biology and ecology (MABE'09), 27 -32 .

Ushiyama, T., Du, M., Inoue, S., Shibaike, H., Yonemura, S., Kawashima, S., and Amano, K., 2009b: Three-dimensional prediction of maize pollen dispersal and cross-pollination and their suppression by windbreaks. Environmental Biosafety Research, 8, 183-202.

牛山朋来・井上 聡・芝池博幸, 2009: 数值シミュレーショ
ンへの適用を目的とした風洞実験と数值実験による防風ネ ッ外の防風特性調査. 農業気象, 65, 273-281.

Yamada, T., 1982: A numerical model study of turbulent airflow in and above a forest canopy. $J$. Meteorol. Soc. Jpn., 60, 439-454.

Yamada, T., and Bunker, S., 1988: Development of a nested grid, second moment turbulence closure model and application to the 1982 ASCOT Brush Creek data simulation. J. Appl. Meteorol., 27, 562 -578 .

Wang, H., and Takle, E. S., 1995: A numerical simulation of boundary-layer flows near shelterbelts. Boundary-Layer Meteorol., 75, 141173.

Wang, H., and Takle, E. S., 1996: On threedimensionality of shelterbelt structure and its influence on shelter effects. Boundary-Layer Meteorol., 79, 83-105.

Wang, H., Takel, E. S., and Shen, J., 2001: Shelterbelts and windbreaks: mathematical modeling and computer simulations of turbulent flows. Annu. Rev. Fluid Mech., 33, 549-586. 